\title{
Sapropel̦a kūdras, sapropel̦a kokskaidu siltumizolācijas plāksnes un to īpašības
}

\author{
Vaira Obuka ${ }^{1}$, Aleksandrs Korjakins ${ }^{2}$, Raitis Brencis ${ }^{3}$, Ilmārs Preikšs ${ }^{4}$, Oskars Purmalis ${ }^{5}$, \\ Karina Stankeviča ${ }^{6}$, Māris Kḷaviņš ${ }^{7}$, \\ ${ }^{2}$ Riga Technical University, ${ }^{3,4}$ Latvian Agricultural University, ${ }^{1,5-7}$ University of Latvia
}

\begin{abstract}
Kopsavilkums. Siltumizolācijas materiāli, kuros par pildvielu tiktu izmantoti vietējie biomasas produkti, bet par saistvielu kalpotu dabiskas izcelsmes saistvielas, piemēram, sapropelis, uzskatāmi par inovatīviem un to pielietošana sekmētu ekologiskās būvniecības nozares attīstību. Šādu risinājumu izstrāde ir aktuāla, jo Latvijā ir ievērojami sapropẹ̦a resursi, kuru izmantošanu kavē to nepietiekama izpēte un ekoloğiskās būvniecības nozares intensīva attīstība. Pētījuma mērķis ir iegūt sapropel̦a-koksnes, kūdras-koksnes siltumizolācijas plāksnes, noteikt optimālās plātnes sastāva attiecības un raksturot iegūto plātņu īpašības. Veikto pētījumu rezultātā tika noteiktas siltumizolācijas materiālu paraugu mehāniskās, siltumvadītspējas un skaņas izolācijas īpašības un izvērtētas iespējas tos izmantot ekologiskajā būvniecībā, kā arī veikts salīdzinājums ar šobrīd tirgū esošajiem produktiem.
\end{abstract}

Atslēgas vārdi: kūdra, sapropelis, sapropeḷa izmantošanas iespējas, ekologiski būvmateriāli, siltumizolācijas materiāli, vietējie resursi, ilgtspējīga izmantošana.

\section{IEVADS}

Ievērojama dal̦a sabiedrības resursu ir jāizmanto mājokḷa uzturēšanai un apsildei, tāpēc īpaši svarīgi ir efektīvu un videi draudzīgu siltumizolācijas materiālu izstrāde, izmantojot vietējos resursus. Ekologiskās būvniecības materiālu attīstība un to pieaugošais izmantošanas īpatsvars būvniecībā kḷūst arvien plašāks tāpēc, ka tas dod iespēju ekonomēt resursus ražošanas laikā un nerada piesārņojumu apkārtējā vidē. Šādi materiāli ir piln̄̄bā pārstrādājami, turklāt sadalās relatīvi ātri pēc to ekspluatācijas. Siltumizolācijas materiāli, kuros par pildvielu tiktu izmantoti koksnes atkritumi (skaidas), bet par saistvielu kalpotu dabiskas izcelsmes saistvielas, piemēram, sapropelis, uzskatāmi par inovatīviem, un to pielietošana sekmētu būvniecības nozares konkurētspēju. Šādu risinājumu izstrāde ir aktuāla, jo Latvijā ir ievērojami sapropel̦a resursi, kuru izmantošanu kavē to nepietiekama izpēte. Sapropel̦a krājumi Latvijā ezeros sasniedz 700 - 800 milj.m ${ }^{3}[1]$, bet purvos zem kūdras slāna 1,5 miljardi $\mathrm{m}^{3}[2]$. Tajā pašā laikā sapropel̦a ieguve var sekmēt degradētu un aizaugušu ezeru atjaunošanu, uzlabot saldūdens resursu kvalitāti, palīdzēt attīstīt dažādas saimniecības nozares, piemēram, zivsaimniecību, hidroenerǵētiku, lauku tūrismu.

Sapropelis ir organogēns nogulumiezis (recekḷveidīga dažādu nokrāsu masa), kas ir veidojies no ūdens augiem un dzīvnieku, galvenokārt planktona, atliekām stāvošos vai vāji cauri tekošos ūdens baseinos [3]. Atkarībā no organisko vielu daudzuma, tās masas veidojošajiem organismiem, sapropel̦a minerālās daḷas masas un sastāva, sapropelis tiek iedalīts
3 tipos: biogēnais, klastiskais un jauktais. Par vērtīgāko ar plašām izmantošanas iespējām pieņem biogēno sapropeli, kuru iedala organogēnajā un kramainajā sapropelī. Biogēna sapropeḷa organisko vielu daudzums nav mazāks par $70 \%$, un tā organiskās masas veidotāji var būt zaļaļǵes, zilalı̆ges, kramal̦ǵes, ūdens dzīvnieki un kūdras veidotājaugi [4].

Latvijā ezeros apmēram $80 \%$ gadījumu organiskās vielas saturs sapropeḷa sausnā ir lielāks par 60\% [5], kas norāda uz to, ka sapropel̦a resursi Latvijā ir augstvērtīgi un ar plašām izmantošanas iespējām.

Biogēnam sapropelim ir konstatētas līmvielas îpašības, kuras raksturo - salīmējoša un hidrofobizējoša spēja. Šim sapropelim ir labs plastiskums, viskozitāte, adhēzijas īpašības un adsorbcijas spējas [6], kā arī saistīgums. Lielāko ieguldījumu sapropel̦a līmējošo īpašību izveidei sniedz slāpekli saturošas vielas, tajā skaitā brīvās aminoskābes un humusvielas. Tāpēc sapropelis var būt izmantojams kā saistvielas piedeva kokmateriālu atkritumiem, linu apstrādes, papīra-kartona ražošanas rūpniecības neizmantotajiem atkritumiem [7], kokšķiedru plātņu izgatavošanai, kuras paredzētas celtniecības materiālu izstrādei. Sapropelis izmantots arī cementa un citu saistvielu aizstāšanai, iegūstot sapropeļbetonu, kas ir celtniecības materiāls, kuram par saistvielu ir nemts organiskais sapropelis, bet par pildvielu zāǵu skaidas un grants [8], [9]. Tiem var pievienot arī veldzētus kalı̧,kus, smilti, lai palielinātu mehānisko izturību. Sapropeḷa saistvielas īpašības izmantojamas, izgatavojot celtniecībai noderīgus materiālus, gan karstā veidā (līmspiedē paaugstinātā temperatūrā un spiedienā), gan arī izgatavojot tos aukstā veidā - blietēšanas paṇēmieni [8].

Neskatoties uz pētījumu rezultātiem, kas tika veikti 20. gadsimta 60., 70. gados un pierādīja sapropel̦a izmantošanas augsto potenciālu, šis pētījumu un praktiskas izmantošanas virziens neattīstījās. Mūsdienās aktualizējoties jautājumiem par tautsaimniecība, kas izmanto vietējos dabiskas izcelsmes resursus, sapropel̦a izpētes virziens būvmateriālu izmantošanā kḷūst aktuāls.

Videi draudzīgas būvniecības pamatā ir izstrādāti šādi principi:

1) konstrukcijās un apdarē jāizmanto dabiski materiāli, materiāli pēc èkas vai tās daļas nokalpošanas otrreizēji jāizmanto;

2) būvmateriālu pārstrāde l̦auj iegūt jaunus produktus, nenodarot kaitējumu dabai;

3) materiālu ekonomija - materiāliem jāsniedz energoresursu ekonomijas iespējas, jāizmanto atjaunojami resursi, kur tiek 
ieklauta izejmateriālu ieguve, ražošana, iepakojums, uzstādīšana, lietošana un pārstrāde (utilizācija). Svarīgi ir pieminēt to, ka materiāli neizdala kaitīgus ksīmiskos savienojumus, ir ilgi ekspluatējami [10], [11], [12]. Materiāliem ir jāsniedz visas dizaina funkcijas, jābūt vizuāli un estētiski pievilcīgiem un elpojošiem. Svarīgi ir izvelēties tādus būvmateriālus, kuriem ir labvēlīga iedarbība uz labsajūtu un veselību, mazs enerǵijas patēriņš un nekaitīgs ražošanas process, reǵenerēšanās un atkārtotas izmantošanas iespējas, materiāliem ir jābūt piemērotiem un ir jāizmanto decentralizēta ražošana [13], [14].

Svarīgi ir izvairīties no indīgu aizsarglīdzekļu un saistvielu izmantošanas, lai tas neradītu ekoloǵisku kaitējumu, ja būvmateriāls nonāk apkārtējā vidē [13]. Ilglaicīga ekonomija un racionāla būvniecība ir iespējama, izmantojot dabiskos būvmateriālus un attīstot videi draudzīgas ražotnes. Vietējo materiālu izmantošana un konkrētai vietai raksturīgais būvniecības veids prasa minimālu transportu, un tādā veidā mājai nepieciešamo būvmateriālu ražošanai patērēto enerǵiju samazinātu uz pusi [11], [12].

Viens no svarīgākajiem elementiem, kas ietaupa energoresursus mājoklī ir siltumizolācija. Tās galvenais uzdevums ir pasargāt dzīvojamās platības no siltuma zudumiem vai arī no sasilšanas, piemēram, pagrabu. Siltumizolācijas materiālus izgatavo plātṇu, paklāju un lokšnu veidā. Visefektīvākais siltumizolācijas materiāls ir gaiss, kurš atrodas tieši miera stāvoklī. Ir svarīgi siltumizolācijas materiālu lietošanas laikā pasargāt no samitrināšanās, jo mitrums paaugstina siltumvadītspēju, kā arī pazemina mehānisko izturība [15].

Siltumizolācijas materiālus ir iespējams izgatavot no organiskām un arī no neorganiskām vielām. Organiskos siltumizolācijas materiālus gatavo no koksnes atkritumiem, kūdras, vilnas, salmiem, koksnes šķiedrām [16], [17]. Plašāk no organiskajiem siltumizolācijas materiāliem lieto fibrolītu, kokskaidu un kokšķiedru plātnes. Neorganiskie materiāli ir azbests, stiklšķiedras un minerāli [15]. Atkarībā no materiāla izcelsmes vietas to var iedalīt trīs grupās - minerālu, sintētiskie un atjaunojamie. Dažos gadījumos produkti var saturēt maisījumu komponentes, piemēram, kaņepju un kaļķa, fibrolīta - koka, vilnas un cementa sajaukumu [11].

Latvijā viens no dabiskajiem materiāliem, kuru var pielietot siltumizolācijas materiālu ražošanā, ir kūdra, jo kūdra ir salīizinoši lēts un viegli pieejams materiāls [18].

Pētījumu rezultāti par sapropel̦a izmantošanu būvniecībā liecina, ka sapropelis ir konkurētspējīgs siltumizolācijas materiālu izveides komponents. Sapropel̦betons ir izmantojams gan siltuma izolācijai (rūpnīcas ēku, saldētavu sienu un pārsegumu, kā arī ierīču un cauruļvadu, gan arī slodzi nenesošu sienu un šksērssienu veidošanai [19]. Gan sapropel̦betons, gan arī kūdras plātnes ir no pilnībā videi draudzīgiem materiāliem veidots, tāpēc sapropel̦a un kūdras siltumizolācijas materiālu izveide ir cieši saistīta ar ekoloǵisko būvmateriālu nozari.

Siltumizolācijas materiālu kritērijus vai funkcijas un kvalitātes īpašības nosaka un regulē likumdošana, un tiem ir izstrādāti starptautiski piemērojami standarti. Šie kritēriji ir izstrādāti, arī balstoties uz vides prasībām, lielā mērā ņemot vērā dz̄̄ves cikla ilgumu. Vācijā ir izstrādāta Eiropas kvalitātes zīme „Natureplus”, kas nosaka būvniecības materiālu standartus, kas atbilst materiāla tehniskajiem parametriem un iekḷauj arī ekologisiskā materiāla kvalitātes zīmi. „Naturplus” kvalitātes zīme ir piešķirta tādiem siltumizolācijas materiāliem kā linu, kaņepju, aitu vilnas, korksu un citu izejvielu materiāliem [16], [20].

Pētījuma mērķis ir noskaidrot iespējas iegūt sapropel̦akoksnes, kūdras-koksnes siltumizolācijas plāksnes, noteikt optimālās plātnes sastāva attiecības un raksturot iegūto plātņu mehāniskās, siltumvadītspējas un skaņas izolācijas īpašības, kā arī to izmantošanas iespēju izvērtējumu ekolog̣isko būvmateriālu nozarē.

\section{MATERIĀLI UN METODES}

\section{Materiāli}

Kūdras-kokskaidu kompozītmateriālu izveidē laboratorijā tika izvēlēta Baložu kūdras lauka kūdra ar $73 \%$ mitruma. Darbā izmantotās kokskaidas ir 0-1,5 cm garas priedes koka skaidas [21]. Sapropelis tika iegūts Pilvel̦u ezerā, kas ir eitrofs ezers, kurš atrodas Latgales augstienē, Rāznas paugurainē. Sapropel̦a virsējais $30 \mathrm{~cm}$ biezais slānis tika iegūts ar kameras tipa mīksto iežu urbi. Materiālu izgatavošanā tika izmantots kūdrains sapropelis ar pelnu saturu $11 \%$ un organisko vielu saturu $-89 \%$, karbonātu saturu - 0,45\%. Izejas sapropeḷa mitrums ir $92 \%$ un blīvums ir $1,11 \mathrm{~g} / \mathrm{cm}^{2}$ [22].

\section{Kompozītmateriālu izgatavošana}

Aktivētās kūdras masa ar saistvielas īpašībām tika iegūta, kūdru apstrādājot mehāniski - termisko ložu planetārajās dzirnavās RETSCH PM 400. Aktivēto kūdras masu sagatavoja, izmantojot $300 \mathrm{~g}$ kūdras un ievietojot malšanas traukā kopā ar 8 malšanas bumbām un malšanu veicot 30 min ar 300 apgriezieniem minūtē. Sapropelis pirms siltumizolācijas materiālu iegūšanas netika ne mehāniski, ne termiski apstrādāts, bet uzreiz sajaukts kopā ar skaidām. Sapropel̦a un koksnes skaidu sajaukšana (izejvielu masas attiecības 1:3) tika veikta manuāli līdz vienmērīgas masas iegūšanai. Pēc tam iegūtā masa tika ievietota veidnē $(30 \times 30 \mathrm{~cm}$ ar regulējamu augstumu) un noblīvēta pie $0,03 \mathrm{MPa}$ spiediena 3 stundas, lai nodrošinātu blīvāku kompozītmateriāla struktūru, paaugstinātu tā mehānisko izturību, samazinātu galaprodukta rukumu, kā arī rukuma plaisu veidošanos. Sapropel̦a-kūdras kompozītmateriāla plāksnes 24 h tika žāvētas $25^{\circ} \mathrm{C}$ un $24 \mathrm{~h} 105^{\circ} \mathrm{C}$.

\section{Kompozìtmateriālu testēšana}

Kompozītmateriālu testēšanai tika sagatavoti gatavā materiāla paraugi ar atšksirīgu mitruma daudzumu: $0,5,10$, $15 \%$. Salizturības pārbaude tika veikta, plāksnes izturot pie $18{ }^{\circ} \mathrm{C} \quad 4$ stundas, tad 4 stundas pie $+20{ }^{\circ} \mathrm{C}$ līdz pilnīgai sasilšanai un tad atkārtoti atdzesējot. Siltumvadītspējas un mehāniskās pārbaudes tika veiktas pēc 5, 10 un 25 saldēšanasatkušanas cikliem. Kompozītmateriālu paraugiem tika noteiktas mehāniskās, siltumizolācijas un akustiskās īpašības, kā arī veikta izgatavoto materiālu degamības testēšana. 


\section{Siltumizolācijas īpaš̄̄bas}

Siltumvadītspēja tika noteikta sausām $(0 \%)$ un mitrām plātnēm (15\%), kā arī pēc saldēšanas atkušanas ietekmju izpētes $\quad(5,10,25$ cikli), iegūstot sakarību starp siltumvadītspējas koeficientu un izstrādājuma mitrumu pakāpi. Saldēšanas-atkušanas ietekmju izpēte tika veikta klimata kamerā (Environmental Chamber JHT Series, Model No. YHT-100 z/07-394B. [23]. Sagatavojot materiālus mehāniskajām pārbaudēm klimata kamerā saldēšanasatkušanas apstākḷi: temperatūras amplitūda no $+20{ }^{\circ} \mathrm{C}$ līdz $18^{\circ} \mathrm{C}$, ilgums 8 stundas. Mitrums klimata kamerā pie pozitīvas temperatūras sasniedza $95 \%$.

Siltumizolācija tika mērīta, izmantojot LaserComp FOX 600 siltumizolācijas mērītāju. Tehniskā informācija nosaka, ka paraugu noteikšanas precizitāte ir $0,025 \mathrm{~mm}$. Tests tika veikts ar paraugu biezuma automātisko noteikšanu (parametru intervāls: biezums - $203 \mathrm{~mm}$, platums $-610 \mathrm{~mm}$ ). Ierīcei ir divas horizontālās plātnes, kuras nodrošina nepieciešamo temperatūru no $-15^{\circ} \mathrm{C} l \overline{1} \mathrm{dz}+85^{\circ} \mathrm{C}$. Abās ierīces devēju plātnēs ir iestrādāti jutīgi sensori siltumplūsmas mērīšanai, un tie atrodas plātṇu vidū. Ierīces vadītspējas diapazons ir no 0,001 līdz 0,35 W/mK [24].

Papildus iepriekš minētajām metodēm, tika noteikts kompozītmateriāla siltumapmaiņas procesa ātrums. Lai iegūtu rezultātus starp plātnēm, tika ievietots termometrs, kas nosaka materiāla virmas temperatūras pieaugumu atkarībā no laika. Tas tika veikts, termometru ievietojot starp kompozītmateriāliem, tiem veicot saldēšanas ciklus saldētavā. Process tika vadīts, izmantojot programmatūru Sarmalink_61_offline.

\section{Materiāla mehānisko īpašību testēšana}

Lai salīdzinātu kūdras-koksnes plātnes un sapropeḷakoksnes plātnes mehānisko izturību savā starpā un ar citiem siltumizolācijas materiāliem, tiem tika veiktas mehāniskās pārbaudes, tos slogojot speciāli paredzētā iekārtā. Mehāniskās pārbaudes tika veiktas paraugiem, kuriem veikta saldēšanas ciklēšana 5, 10, 25, 54 un 69 reizes un dažāds mitruma saturs: 0, 5, 15\%. Mehāniskās pārbaudes tika veiktas uz 5985 Floor Model Universal Testing System iekārtas, kas paredzēta materiālu stiprības noteikšanai statiskā slogojumā, mērījumu precizitāte ir +/- $0.5 \%$, mērījumi tiek nolasīti datorā, kurš ir tieši savienots ar ierīci (Savietojams ar Bluehill ® Software). Būtisku iespaidu uz mehānisko pārbaužu rezultātiem atstāj slogošanas ātrums, testos izmantotais slogošanas ātrums bija robežās no $0,0005 \mathrm{l} \overline{\mathrm{d}} \mathrm{z} 1016 \mathrm{~mm} / \mathrm{min}$. Iekārtas slodzes devēja spēks ir 250kN. Vertikālā testa telpa ir $1430 \mathrm{~mm}$, bet augstums ir $1930 \mathrm{~mm}$ [25].

Paraugu mehāniskā pārbaude spiedē tika īstenota paralēli paraugu formēšanas virzienam, kas tika izvēlēts saistībā ar paraugu struktūras īpatnībām, īpaši ņemot vērā mehāniskai pārbaudei domātu paraugu sagatavošanas specifiku (paraugu šksērsgriezumā pildvielas lielākoties atrodas horizontālā plaknē).

\section{Skaņas izolācijas īpašības}

Materiāliem tika veikta arī skaņas izolācijas pārbaude. Iekārtas standarts ir ar numuru LVS EN ISO 10534-2:2002 un nosaukumu - „Akustika - Skaņas absorbcijas koeficienta un pilnās pretestības noteikšana pilnās pretestības caurulēs", izmantojot pārejas funkcijas metodi [26]. Tiek izmantota 4 mikrofonu metode akustiskā caurulē (Brüel\&Kjær. Impedance/Transmission Loss Measurement Tubes. Type 4206. The Four-microphone Method with PULSE Acoustic Material Testings oftware - Type 7758.) [27].

Skaņas izolācija ir pārvades zudums jeb skaņas redukcijas indekss R (dB), ir grīdas, sienas, durvju vai kāda cita šķēršḷa, kas ierobežo skaṇas kustību, efektivitātes mērvienība. Skaņas pārvades zuduma mērvienība ir decibels (dB). Jo augstāks ir sienas skaṇas pārvades zudums, jo labāk tā ierobežo nevēlamu skaṇu iekḷūšanu [28].

Iekārta darbojas pēc principa, ka tās vidū tiek ievietots paraugs starp 2 ǵipša plātnēm, bet caurules galā ir sūklis, kas absorbē skaṇu, lai tā neatbalsotos. Parauga diametrs, kas tika ievietots akustiskajā caurulē ir $98-99 \mathrm{~mm}$, bet biezums $45-$ $50 \mathrm{~mm}$.

Kūdras-kokskaidu un sapropel̦a kokskaidu un priedes koka pašaizdegšanās rezultātu salīdzinājums

Lai spriestu par kompozītmateriālu degšanas raksturlielumiem, tika veiktas vienkāršas degšanas pārbaudes. Tika noteikta temperatūra, pie kuras sākas paraugu pašaizdegšanās. Degšanas eksperimentiem tika izmantota mufeḷkrāsns SNOL. Porcelāna tīǵel̦os tika ielikti paraugi (kūdras-kokskaidas, sapropelis-kokskaidas, kokskaidas) un ievietoti mufelī, uzstādot vienmērīgu $\mathrm{T}^{\circ} \mathrm{C}$ pieaugumu līdz $500^{\circ} \mathrm{C}$. No katra materiāla mufelī tika ielikti 3 paraugi, karsēšanas procedūru atkārtojot 3 reizes.

\section{III.REZULTĀTI UN DISKUSIJA}

Kompozītmateriālus veido vienā gadījumā aktivētā kūdra (saistviela) un kokskaidas (pildviela), bet sapropeḷakokskaidu plātnēs, kā saistvielas tiek izmantots neapstrādāts sapropelis, bet pildvielas - kokskaidas. Kūdras-kokskaidu plātnes izgatavošanai tika izmantota [18] izstrādāta metode, bet sapropel̦a-kokskaidu plātnes izgatavošanas metode ir oriǵināla.

Iegūtās plātnes ir vieglas, porainas un viegli drūpošas. Sapropel̦a-kokskaidu plātne ir drupenāka par kūdraskokskaidu plātni. Sapropeḷa-kokskaidu plātnei krāsa ir zaļgana, gaiši brūna, bet kūdras-koksnes kompozītmateriāla krāsa ir tumši brūna. Izveidoto plātṇu augstums ir 4,5 $5,5 \mathrm{~cm}$, bet platums $29,3-30,1 \mathrm{~cm}$. Iegūto plātñu vidējais blīvums ir $234,3 \mathrm{~kg} / \mathrm{m}^{3}$. Minēto parametru vērtības ir atkarīgas no plātnes formēšanas apstākl̦iem. Plātnēm ir sīkporaina uzbūve ar viendabīgu šksiedru struktūru ar val̦ejām un savā starpā savienotām porām. Plātņu izgatavošanas procesā nav nepieciešams speciāls apǵērbs vai citi īpaši aizsardzības līdzekḷi - jo izejvielas nav veselībai kaitīgas un izgatavošanas procesā neveidojas kaitīgi izgarojumi. N̦emot vērā plātnuu iegūšanas apstākḷus, izmantotā sapropel̦a, kūdras un kokskaidu 
ipašību variabilitāti, ir iespēja iegūt minētos kompozītmateriālus ar plašu īpašību intervālu.

Tika pētītas iegūto kompozītmateriālu mehāniskās īpašības: noturība pret lieces (1.tabula) un spiedes īpašībām (2.tabula). Laboratorijas apstākḷos izveidotajiem paraugiem tika veiktas mehāniskās pārbaudes spiedes pretestības un lieces pretestības noteikšanai.

Mehāniskā stiprība siltumizolācijas kompozītmateriāliem tika pārbaudīta, tos pirms tam testējot pēc sala izturības pārbaudes nosacījumiem, pamatojoties uz N. Brakša pētījumiem par sapropeļbetonu [9]. Salizturības pārbaude ir būtiska, lai pārbaudītu izstrādāto materiālu ekspluatācijas iespējas Latvijas klimatiskajos apstākḷos. Atšķkirībā no N. Brakša pētîjumiem, kad paraugi tieši pirms mehāniskajām pārbaudēm bija pilnībā jāiegremdē ūden̄̄, šajā pētījumā netika veikta šāda manipulācija. Salizturības testēšana tika veikta pilnībā izžāvētam paraugam, kā arī ar mitrumu piesātinātam (15\%), kā arī pēc saldēšanas - atkušanas cikliem $(5 x, 10 x$, $25 \mathrm{x})$.

Iegūtie rezultāti sniedz ieskatu par Latvijā pieejamās kūdras un sapropeḷa augsti tehnoloǵiskās izmantošanas iespējām, tai skaitā būvniecībā, siltumizolācijas materiālos, kā kompozītmateriālos saistvielas veidā. Aktivētas kūdras kā saistvielas iegūšana ļauj izmantot iespēju to aktīvi transportēt un uzglabāt ilgākā laika posmā.

1.TABULA

LIECES MEHĀNISKĀ STIPRĪBA ATKARĪBĀ NO MITRUMA PIESĀTINĀJUMA UN SALDËŠANAS CIKLU SKAITA

\begin{tabular}{|c|c|c|c|c|}
\hline \multirow{2}{*}{$\begin{array}{c}\text { Testētās } \\
\text { plātnes veids }\end{array}$} & \multicolumn{2}{|c|}{ Kūdra-koksne } & \multicolumn{2}{c|}{ Sapropelis-koksne } \\
\cline { 2 - 5 } & $\begin{array}{c}\text { Slodze } \\
\text { liecē, N }\end{array}$ & $\begin{array}{c}\text { Lieces } \\
\text { stiprība, } \\
\text { Mpa }\end{array}$ & $\begin{array}{c}\text { Slodze } \\
\text { liecē, N }\end{array}$ & $\begin{array}{c}\text { Lieces } \\
\text { stiprība, } \\
\text { Mpa }\end{array}$ \\
\hline sauss (0 \%) & 112 & 0,153 & 11 & 0,015 \\
\hline mitrs (15\%) & 125 & 0,164 & 18 & 0,021 \\
\hline gaisa sauss (5\%) & 111 & 0,284 & n.a. & n.a. \\
\hline $5 X$ & 232 & 0,351 & 20 & 0,028 \\
\hline $10 \mathrm{X}$ & 269 & 0,386 & 20 & 0,027 \\
\hline $25 \mathrm{X}$ & 341 & 0,409 & 20 & 0,026 \\
\hline
\end{tabular}

Pēc norādīto reižu skaita (X) - sasalšanas-atkušanas ciklu skaits.

Izmantotā tehnologija [18], salīdzinot ar plaši izmantotām kūdras un sapropel̦a siltumizolācijas materiālu izveides tehnoloǵijām, prasa mazāku enerğijas patēriņu, jo pirmkārt tiek izmantoti vietējie resursi, bet materiāla saistvielas izveidošanas laiks un patērētā enerǵija ir daudz mazāka. Svarīgi ir pieminēt žāvēšanas laiku, kas tiek pielietots daudz mazākā mērā, un tas liecina par šādas tehnoloǵijas zemāku energoietilpību.

Izejvielu un gala produktu pārstrādājamība atbilst ierobežotu pasaules resursu lietderīgās izmantošanas tendencēm. Tieši runājot par sapropel̦a izmantošanu siltumizolācijas materiālos, mērḳis ir panākt sapropel̦a lietošanu ar mazāku enerǵijas pievienošanu pārstrādes laikā, salīdzinot ar kūdras-kokskaidu plātnēm, pievienojot sārmu un tādējādi iegūstot augtākus rezultātus mehāniskajās pārbaudēs.
Rezultāti norāda, ka materiāls ir salizturīgs, jo sasaldējot un atkausējot paraugus, to mehāniskā stiprība, kā apliecina pārbaudes rezultāti uz lieci, nav būtiski samazinājušies. No mitruma daudzuma materiālos mainās plātnuu spiedes pretestība. Sapropel̦a-kokskaidu vidējā lieces pretestība ir $0,02 \mathrm{MPa}$, bet kūdras-kokskaidu vidējā spiedes pretestība ir $0,3 \mathrm{MPa}$.

Lieces rezultātiem pie izvēlētā paraugu mitruma režīma mehāniskās stiprības izmaiņas nav būtiskas. Pēc literatūras datiem, mehānisko pārbaužu lieces rezultātiem atkarībā no mitruma daudzuma paraugā vajadzētu vienmērīgi samazināties, taču iegūtie rezultāti to neparāda. Šādi gatavotiem kompozītmateriāliem to mehāniskās īpašības nepasliktinās uzņemot gaisā esošo mitrumu, kā arī pēc saldēšanas-atkušanas cikliem, kas paaugstina to potenciālu izmantošanai būvniecībā. Ievērojami mazāka mehāniskā izturība ir sapropel̦a-kokskaidu plātnēm, kas ir atkarīgs ne tikai no materiāla, bet arī tā sagatavošanas, jo sapropelis atšksirībā no kūdras netika apstrādāts, taču šādu manipulāciju veicot arī ar sapropeli, tā mehāniskā izturība varētu pieaugt. Jāatzīmē, ka tika izmantots sapropelis ar ļoti augstu mitrumu (92\%), kuru samazinot varētu iegūt labākas kompozītmateriāla mehāniskās īpašības.

\section{TABULA}

SPIEDES STIPRĪBA ATKARĪBĀ NO PARAUGA MITRUMA PIESĀTINĀJUMA UN SALDĒŠANAS-ATKUŠANAS CIKLU SKAITA

\begin{tabular}{|c|c|c|c|c|}
\hline \multirow[b]{2}{*}{$\begin{array}{c}\text { Testētās } \\
\text { plātnes } \\
\text { veids }\end{array}$} & \multicolumn{2}{|c|}{ Kūdra-koksne } & \multicolumn{2}{|c|}{ Sapropelis-koksne } \\
\hline & $\begin{array}{c}\text { Slodze } \\
\text { spiedē } \\
\text { pie 10\% } \\
\text { defor- } \\
\text { mācijas, } \\
\text { N }\end{array}$ & $\begin{array}{c}\text { Kūdras-- } \\
\text { kokskaidu } \\
\text { kompozīta } \\
\text { stiprība } \\
\text { spiedē pie } 10 \\
\text { \% lineārām } \\
\text { deformā- } \\
\text { cijām, MPa }\end{array}$ & $\begin{array}{c}\text { Slodze } \\
\text { spiedē } \\
\text { pie } 10 \% \\
\text { deformā- } \\
\text { cijas, } N\end{array}$ & $\begin{array}{c}\text { Sapropęa- } \\
\text { kokskaidu } \\
\text { kompoz̄ita } \\
\text { stiprība spiedē } \\
\text { pie } 10 \% \\
\text { lineārām } \\
\text { deformācijām, } \\
\text { MPa }\end{array}$ \\
\hline sauss $(0 \%)$ & 112 & 0,153 & 11 & 0,015 \\
\hline mitrs $(15 \%)$ & 125 & 0,164 & 18 & 0,021 \\
\hline $\begin{array}{c}\text { gaisa sauss } \\
(5 \%)\end{array}$ & 111 & 0,284 & n.a. & n.a. \\
\hline $5 X$ & 232 & 0,351 & 20 & 0,028 \\
\hline $10 \mathrm{X}$ & 269 & 0,386 & 20 & 0,027 \\
\hline $25 \mathrm{X}$ & 341 & 0,409 & 20 & 0,026 \\
\hline
\end{tabular}

Pēc norādīto reižu skaita (X) - sasalšanas-atkušanas ciklu skaits.

Rezultāti norāda uz to, ka materiāls ir sala izturīgs. Atkarībā no mitruma daudzuma mainās plātṇu spiedes pretestība. Sapropel̦a-kokskaidu vidējā spiedes pretestība ir 0,06 $\mathrm{MPa}$, bet kūdras-kokskaidu vidējā spiedes pretestība ir 0,13 MPa. Spiedes pretestības rezultāti norāda uz to, ka kompozītmateriālu stiprība ir pietiekama, lai ar tiem veiktu montāžas darbus, līmējošus savienojumus.

No iegūtajiem rezultātiem var secināt, ka nejaušās spiediena izmaiņas var manāmi ietekmēt izgatavojamo paraugu izturību, tādēc šim apstāklim jāvelta īpaša uzmanība.

Spiedes rezultātu variabilitāti pie izvēlētā paraugu mitruma režīma un saldēšanas ciklu skaita varētu izraisīit kompozītmateriālu izgatavošana un to sagriešana, lai noteiktu 
mehānisko stiprību. Izstrādāto kompozītmateriālu salizturību ietekmē to izgatavošanas process, kurā ir jāpanāk homogēnāka saistvielas un pildvielas samaisīšana. Samazināt rezultātu izkliedi un paaugstināt mehānisko stiprību varētu, pārejot no roku maisīšanas tehnologijas uz mehānisku samaisīšanu.

Tā kā viena no nozīmīgām jebkura būvmateriāla īpašībām ir to spēja izolēt skaņu, tad bakalaura darba ietvaros tika veikta izstrādāto materiālu skaṇas izolācijas îpašību izpēte (3. tabula).

$$
\text { 3.TABULA }
$$

SKAN̦AS IZOLĀCIJAS TESTU REZULTĀTI, IZMANTOJOT 4 MIKROFONU METODI

\begin{tabular}{|c|c|}
\hline Testētā plātne & Skaṇas izolācija, dB \\
\hline Kūdras -koksne & 30 \\
\hline Kūdras -koksne & 32 \\
\hline Sapropelis - koksne & 32 \\
\hline Sapropelis - koksne & 31 \\
\hline
\end{tabular}

Viena no būtiskākajām prasībām ēku būvniecībā ir skaņas izolācija. Pārlieku liels troksnis rada lielu stresa risku un traucē sarunāties, kā arī tiek uztverts kā vides piesārnojums [29].

Iegūtie skaṇas izolācijas rezultāti liecina par kompozītmateriāla l̦oti labām izolācijas īpašībām. Salīdzinot ar citiem ekoloğiskajiem siltumizolācijas materiāliem, piemēram, linu šķiedru siltumizolācijas materiālu, rezultāti ir sliktāki, un tie atšķiras par 14 vienībām. Linu šksiedru materiālam skaṇas absorbcijas rezultāts pēc literatūras datiem ir $45 \mathrm{~dB}$, bet linu - vilnas siltumizolācijas materiāls aiztur $40 \mathrm{~dB}$ skaņas absorbciju [30]. Veicot jaunus pētījumus, rezultātus ir iespējams uzlabot.

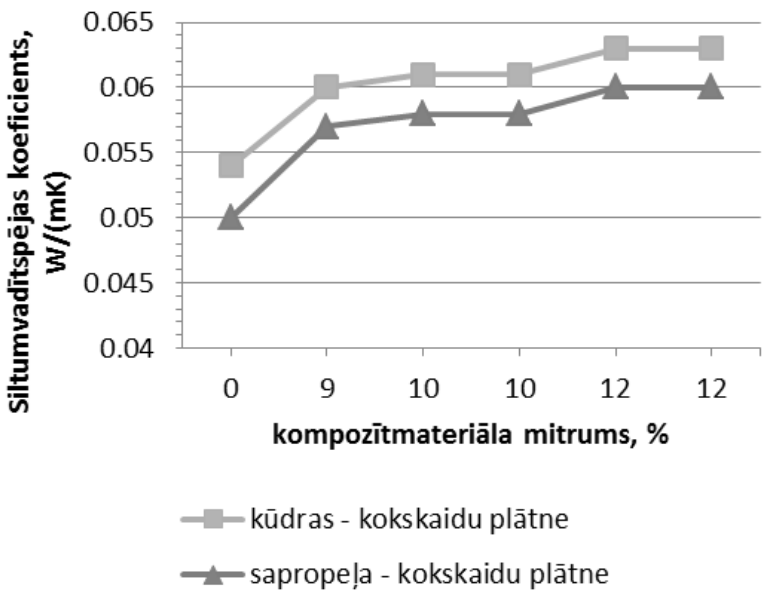

1. att. Kūdras kokskaidu un sapropela - kokskaidu siltumvadītspējas koeficients atkarībā no mitruma piesātinājuma kompozītmateriālā.

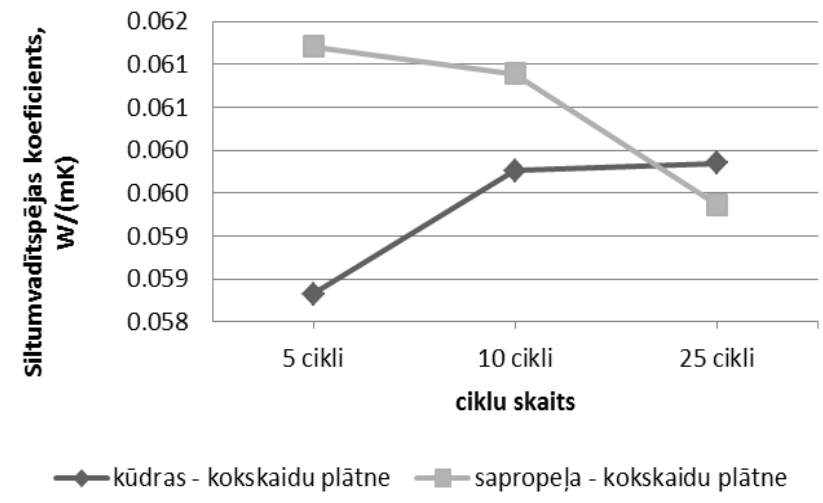

2. att. Kūdras - kokskaidu plātnes un sapropeḷa - kokskaidu plātnes siltumizolācijas koeficients atkarībā no parauga saldēšanas ciklu skaita.

N̦emot vērā skaņas izolācijas īpašības, var secināt to, ka smagāks materiāls ir labāks skaņas izolācijas sfērā. Kā labākos pieejamos skaņas absorbcijas materiālus Latvijā min kokšķiedru universālā pielietojuma plātnes, minerālās vates blīvākos paraugus un kork̦a izstrādājumus [31].

Siltumvadītspēja ir materiāla spēja caurvadīit siltumu no tā vienas virsmas līdz otrai, ja starp tām ir temperatūru starpība, un to raksturo siltumvadītspējas koeficients. Jo mazāks ir šis koeficients, jo kvalitatīvāks ir siltumizolējošais materiāls. Siltumizolāciju lielā mērā ietekmē tilpummasa, mitrums [15] un porainība.

Sapropel̦a-kūdras kompozītmateriāla un kūdras-kokskaidu kompozītmateriāla plātnēm tika veikta siltumvadītspējas pārbaude, mainot plātnes mitruma rādītājus un saldēšanas ciklu skaitu katrai plātnei.

Tika mērīta siltumvadītspēja gan paraugiem, kuriem ir dažāds mitrums (1.attēls), gan paraugiem, kuriem ir dažāds saldēšanas ciklu skaits (2.attēls).

Pēc rezultātiem var spriest, ka kūdras-kokskaidu materiāls un sapropel̦a- kokskaidu materiāls ir ar līdzịgiem rādītājiem, tādējādi šiem siltumizolācijas materiāliem ir līdzīgs potenciāls un izmantošanas iespējas.

Kūdras kokskaidu un sapropeḷa kokskaidu izveidotajām plātnēm ir raksturīga sīkporaina uzbūve ar viendabīgu šķiedru struktūru ar val̦ējām un savā starpā savienotām porām. Ir novērojams tas, ka uz materiāla siltumvadītspēju būtiska ietekme ir mitruma daudzumam. Vidējais sapropel̦akokskaidu siltumvadītspējas koeficients ir $0,067 \mathrm{~W} /(\mathrm{mK})$, bet kūdras-kokskaidu vidējā vērtība ir $0,060 \mathrm{~W} /(\mathrm{mK})$. Kūdraskokskaidu plātnei veicot saldēšanas ciklus, tās siltumvadītspēja nedaudz palielinās, taču sapropel̦a-kokskaidu plātnes koeficients samazinās un kḷūst labāks. To varētu izskaidrot ar saldēšanas procesa izraisītu plātnes žūšanas procesu un materiālā esošā mitruma zudumu, kā rezultātā kompozìtmateriāla poras ūdens tvaiku vietā tiek aizpildìtas ar gaisu, kas ir labāks izolējošais materiāls. Kūdras-kokskaidu plāksnēs mitrums sasniedz koksnes šķiedru piesātināšanas punktu, tālāk materiāla mehāniskās îpašības nepasliktinās un briešana, siltumvadītspēja sasniedz maksimālo vērtību un tālāk nepieaug [32]. Pēc pirmajiem rezultātiem, kas ir veikti ar sapropel̦a-kokskaidu plātnēm, var spriest, ka to izmantošana 
Latvijas apstākḷiem ir ieteicama, jo saldēšanas cikli nepasliktina materiāla īpašības.

Papildus siltumvadītspējas koeficienta mērījumiem un saldēšanas cikliem, tika noteikts siltumvadītspējas koeficienta rezultāts plātnei ar mitruma daudzumu 59\%, kas bija $0,101 \mathrm{~W} /(\mathrm{mK})$. Lai gan tik augsta dabīga materiāla samitrināšanās nenotiek, šie rezultāti norāda uz augsto mitruma ietekmi uz siltumvadītspēju, kas nosaka tās vienlīdzīgas prasības pret visiem izolējošajiem materiāliem, nodrošinot to izolētību no mitruma.

Literatūrā ir atrodami dati par eksperimentiem, kas ir veikti ar sapropel̦a - salmu plātnēm, kas pēc sastāva ir ļoti līdzīgs sapropel̦a-kokskaidu plātnei. Salīdzinot ar sapropel̦akokskaidu plātni, siltumvadītspējas koeficients ir mazāks, tas ir $0,55 \mathrm{~W} /(\mathrm{mK})$. Darbā ir uzsvērts, ka mainot, sapropel̦a un salmu attiecību, ir iespējams panākt labākus rezultātus siltumvadītspējas koeficientam [33]. 4. tabulā minēto kompozītmateriālu īpašību kopums tika vērtēts, n̦emot vērā izmantoto izejvielu (organiska, neorganiska), siltumvadāmības koeficientu, bioloǵisko noturību, mitruma ietekmi un ekoloǵiskās drošības pakāpi. Izvērtējot siltumizolācijas materiālu siltumvadāmības koeficientus, ir skaidri redzams, ka materiāli, kuros tiek izmantotas dabiskas škiedras, ir ar zemāku siltumvadāmības koeficientu. Taču pielietojot šādus materiālus būvniecībā, atkarībā no izmantošanas veida un saskares iespējas, ir jānovērtē arī to mehāniskās īpašības, produkta dzīves ilgumu vai nav alerǵiju izraisošs.

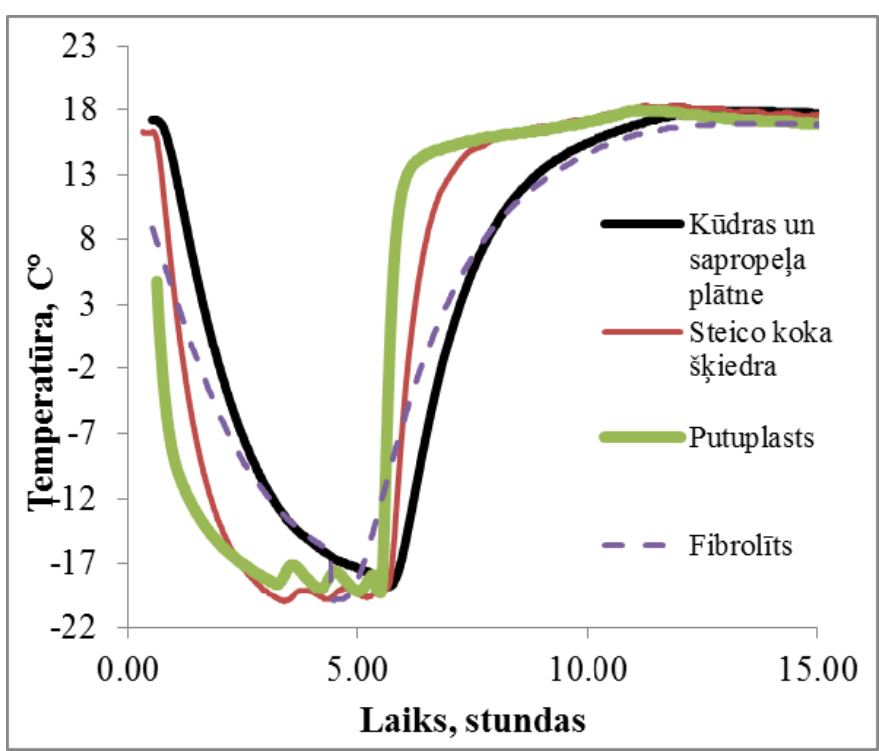

3. att. Testēto materiālu siltumapmaiṇas procesa ātrums.

Eksperimenta rezultāti ar temperatūras izmaiṇu kumulatīvo efektu parāda, ka no salīdzinātajiem materiāliem, kūdras- kokskaidu plātne un sapropel̦a-kokskaidu plātne uzrāda labākos rezultātus (3. attēls). Respektīvi, kompozītmateriāls vislēnāk atdziest, sasniedzot $-20^{\circ} \mathrm{C} 3,8 \mathrm{~h}$ laikā, un tas arī vienmērīgāk uzñem siltumu, sasniedzot $+18^{\circ} \mathrm{C}$. Līdz ar to var spriest, ka materiālam ir vienmērīgāks siltumapmaiņas process un ka to izmantojot konstrukcijās, tam ir izteiktākas termoregulācijas īpašības. Materiāls kḷūst augstvērtīgāks tieši pasīvo māju celtniecības izmantošanā, jo regulē iekšējo ēkas klimatu [39]. Pēc iegūtās informācijas iekšējās virsmas temperatūras svārstības ietekmē materiālu dažādā spēja uzṇemt (akumulēt) siltumu un pēc tam to atdot. Vislabākie siltumietilpības rādītāji ir dabīgam kokam. L,oti būtisks rādītājs ir tas, cik ātri ārsiena atdod saglabāto siltumu, tas ir, kāds ir tās atdzišanas ātrums. Ja atdzišana notiek ļoti strauji, tad palielinās izmaksas par apkuri, jo, lai uzturētu nemainīgu nepieciešamo iekšējo gaisa temperatūru, biežāk jāieslēdz apkures sistēmu [40]. Pateicoties tam, vasaras karstajās dienās telpās tiek nodrošināts patīkams vēsums, bet ziemas periodā mājīgs siltums.

Tika veikts izstrādāto materiālu degšanas riska novērtējums (5. tabula).

$$
\text { 5.TABULA }
$$

KŪDRAS - KOKSKAIDU UN SAPROPEL̨A KOKSKAIDU UN PRIEDES KOKA PAŠAIZDEGŠANĀS ĪPAŠİBU SALĪDZINĀJUMS

\begin{tabular}{|c|c|c|}
\hline Parauga veids & $\mathbf{T}^{\circ} \mathrm{C}$ & $\mathrm{T}^{\circ} \mathrm{C}$, vid. aritmēt. \\
\hline \multirow{3}{*}{ Kūdras - kokskaidu plātne } & 345 & \multirow{3}{*}{333} \\
\hline & 330 & \\
\hline & 325 & \\
\hline \multirow{3}{*}{ Sapropeḷa - kokskaidu plātne } & 290 & \multirow{3}{*}{296} \\
\hline & 295 & \\
\hline & 302 & \\
\hline \multirow{3}{*}{ Priedes koka skaidas } & 345 & \multirow{3}{*}{345} \\
\hline & 340 & \\
\hline & 350 & \\
\hline
\end{tabular}

Uz degšanas pārbaudes iegūto datu pamata ir iespējams secināt to, ka kūdras kokskaidu plātnes pašaizdegšanās temperatūra ir augstāka, nekā sapropel̦u-kokskaidu plātnes pašaizdegšanās temperatūra. Tas izskaidrojams ar to, ka paraugi atšksiras pēc blīvuma un šķiedru izkārtojuma paraugos. Respektīvi, kūdras kokskaidu plātnes šksiedru izkārtojums ir blīvāks un starp tām ir mazāk gaisa, taču sapropeḷa-kokskaidu plātne ir trauslāka un ar ievērojami zemāku mehānisko izturību. Izmantojot šādu izgatavošanas metodi, šķiedrainā struktūra, kas rodas paraugā, ir ar lielāku daudzumu gaisa, un tas samazinu temperatūru, kurā paraugam sākas pašaizdegšanās (ir lielāka oksidētāja - gaisa skābekḷa daudzumu klātbūtne). 
4.TABULA

DAŽĀDU SILTUMiZOLĀCIJAS MATERIĀLU RĀDĪTĀJU SALĪDZINĀŠANAS TABULA [9], [34], [35], [36], [37], [38]

\begin{tabular}{|c|c|c|c|c|c|}
\hline Rādītāji & Izejviela & $\begin{array}{c}\text { Siltumvadāmība, } \\
\mathbf{W} / \mathbf{m}^{3}\end{array}$ & $\begin{array}{c}\text { Bioloǵiskāa } \\
\text { noturība }\end{array}$ & $\begin{array}{l}\text { Mitruma } \\
\text { ietekme }\end{array}$ & $\begin{array}{l}\text { Ekoloǵiskā } \\
\text { drošība }\end{array}$ \\
\hline Ekovate & $\begin{array}{c}\text { Celulozes šksiedra, dabas } \\
\text { minerāli (borāti) }\end{array}$ & $0,038-0,041$ & $\begin{array}{l}\text { Novēršs sēnīšu } \\
\text { attīstīšanos }\end{array}$ & Neietekmē & Absolūti nekaitīga \\
\hline Stikla šķiedra & Smilts, kal̦ķakmens, soda & $0,047-0,052$ & Nav datu & Nosēžas & Nav datu \\
\hline $\begin{array}{c}\text { „Geokars" } \\
\text { siltumizolācijas } \\
\text { materiāls }\end{array}$ & Kūdra, kokskaidas & $0,047-0,08$ & Nav datu & Neietekmē & Absolūti nekaitīgs \\
\hline $\begin{array}{l}\text { Minerālvates } \\
\text { plāksnes }\end{array}$ & $\begin{array}{l}\text { Metalurǵijas sārņi, kalnu } \\
\text { ieži, saistošs - fenola } \\
\text { spirts vai bitumens }\end{array}$ & $0,047-0,084$ & $\begin{array}{c}\text { Noturīga pret } \\
\text { sēn̄̄šsu } \\
\text { iedarbību }\end{array}$ & Nav datu & $\begin{array}{l}\text { Ekspluatācijas } \\
\text { laikā izraisa } \\
\text { kaitīgas vielas }\end{array}$ \\
\hline Sapropel̦betons & $\begin{array}{l}\text { Sapropelis, zāǵu skaidas, } \\
\text { smilts, grants, māli, }\end{array}$ & 0,035 & $\begin{array}{l}\text { Noturīgs pret } \\
\text { sēn̄̄šu } \\
\text { iedarbību }\end{array}$ & $\begin{array}{c}\text { Samazinās } \\
\text { mehāniskā } \\
\text { izturība un } \\
\text { siltumvadītspēja }\end{array}$ & Absolūti nekaitīgs \\
\hline $\begin{array}{l}\text { Sapropela - } \\
\text { kokskaidu } \\
\text { plātne }\end{array}$ & Sapropelis, kokskaidas & 0,067 & Nav datu & $\begin{array}{c}\text { samazinās } \\
\text { mehāniskā } \\
\text { izturība un } \\
\text { siltumvadītspēja }\end{array}$ & Absolūti nekaitīga \\
\hline $\begin{array}{l}\text { Kūdras - } \\
\text { kokskaidu } \\
\text { plātne }\end{array}$ & Kūdra, zāğu skaidas & 0,06 & Nav datu & $\begin{array}{c}\text { samazinās } \\
\text { mehāniskā } \\
\text { izturība un } \\
\text { siltumvadītspēja }\end{array}$ & Absolūti nekaitīga \\
\hline Aitas vilna & $\begin{array}{c}85 \% \text { ir dabīgā vilna un } \\
15 \% \text { poliesteris }\end{array}$ & 0,039 & Nav datu & Neietekmē & Nav datu \\
\hline Fibrolīts & $\begin{array}{l}\text { koka ēvelskkaidas, } \\
\text { cements un ūdens }\end{array}$ & 0,068 & Noturīgs & Neietekmē & $\begin{array}{l}\text { Dabai nekaitīgs } \\
\text { materiāls }\end{array}$ \\
\hline Perlīts & $\begin{array}{l}\text { vulkāniskas izcelsmes } \\
\text { stiklveida ieži }\end{array}$ & $0,045-0,05$ & Nav datu & Nav datu & Nav datu \\
\hline $\begin{array}{c}\text { Stiprināti } \\
\text { kaṇepes spaḷi }\end{array}$ & $\begin{array}{c}\text { neapstrādāti un } \\
\text { mineralizēti kaņepes } \\
\text { spaḷi }\end{array}$ & 0,048 & Augsta & Nav datu & Nav datu \\
\hline $\begin{array}{l}\text { „Steicoprotect" } \\
\text { koka šķiedras }\end{array}$ & kokmateriālu atgriezumi & 0,040 & Nav datu & Nav datu & Nav datu \\
\hline Arbolīts & $\begin{array}{l}\text { koksnes svek̦ainās } \\
\text { šķiedrās un minerālas } \\
\text { saistvielas (cementa } \\
\text { vaimagnija oksīds) }\end{array}$ & $0,09-0,10$ & Augsta & Neietekmē & Nav datu \\
\hline Uzpūsts korḳis & korķozola mizas & $0,032-0,045$ & Augsta & Nav datu & Nav datu \\
\hline Lins & $\begin{array}{l}\text { auga īsās šķiedras, bora } \\
\text { sāls, nātrija silikāts }\end{array}$ & $0,037-0,065$ & Nav datu & Nav datu & Nav datu \\
\hline $\begin{array}{c}\text { Kaṇepju - kal̦ksa } \\
\text { kompozìtmate- } \\
\text { riāls }\end{array}$ & Kan̦epju spal̦i, saistviela & 0,0713 & Nav datu & Nav datu & Nav datu \\
\hline Fibrolīts & $\begin{array}{l}\text { koka ēvelskaidas, } \\
\text { cements un ūdens }\end{array}$ & 0,068 & Noturīgs & Neietekmē & $\begin{array}{l}\text { Dabai nekaitīgs } \\
\text { materiāls }\end{array}$ \\
\hline
\end{tabular}

Svarīgi ir pieminēt to, ka koksne ir anizotrops materiāls un tās fizikālās, kā arī mehāniskās īpašỉbas ir ciešā sakarā ar to, kāds ir šķiedru virziens, kuras izmanto [32]. Pēc pārbaudēm var spriest, ka iegūtie materiāli ir ieskaitāmi degošu materiālu grupā, jo, iedarbojoties aizdedzināšanas avotam uz kompozītmateriālu, tas aizdegas, gruzd vai pārogḷojas. Pēc aizdedzināšanas avota iedarbības izbeigšanās tas turpina degt, gruzdēt vai pārogloties. Lai uzlabotu kompozîtmateriāla aizsardzību pret uguni un paaugstinātu ugunsdrošību, ir jāveic nepieciešamie ugunsdrošības pasākumi, kā arī jānodrošina materiāla izolētība, piemēram, izmantojot ğipškartona loksnes. Siltumizolācijas plātnes uz koksnes pamata ir iespējams 
apstrādāt ar antipirēnu, padarot to par grūti degošu vai nedegošu siltumizolācijas materiālu [41], un šis pats risinājums ir izmantojams arī izstrādātajām kūdras-kokskaidu un sapropeḷa-kokskaidu plāksnēm, piemēram, pievienojot borskābes piedevas vai citus maztoksiskus antipirētiķus.

Koksnes materiālus apstrādājot ar pretuguns aizsardzības līdzekḷiem, tajos samazinās tādi rādītāji, kā liesmas izplatība, degšanas jauda, uguns reakcija. Pastāv divu veidu pretuguns aizsardzības veidi - koksnes piesūcināšana un apdare. Koksnes piesūcināšana ir koksnes virspusēja apstrāde ar darba šķīdumu, to apsmidzinot [42]. Lai pilnveidotu materiālu izmantošanas iespēju, tie ir jāapstrādā ar dažādiem līdzekḷiem, kas uzlabo ugunsdrošības rādītāju un bioloǵisko noturību, jo tas palielina kompozītmateriālu ilgmūžīibu un izmantošanas iespējas.

\section{SECINĀJUMI}

Izmantojot vietējās izejvielas (kūdru, sapropeli, koksnes skaidas), ir iespējams izstrādāt videi draudzīgus siltumizolācijas materiālus izmantošanai būvniecībā. Izmantojot sapropeli kā līmvielu, pirmo reizi iegūts sapropeḷa-kokskaidu siltumizolācijas kompozītmateriāls. Kūdras-kokskaidu un sapropel̦a-kokskaidu kompozītmateriāla mehāniskās, skaņas izolācijas un siltumizolācijas rādītāji ir augsti un salīdzināmi ar tirgū piedāvātajiem siltumizolācijas materiāliem. Pētītos kūdras-kokskaidu un sapropeļakokskaidu kompozītmateriālus ir iespējams izmantot ekologískajā būvniecībā kā siltumizolācijas materiālu, kā arī, paaugstinot mehānisko izturību, par ēku struktūras elementiem. Iegūtie materiāli teicami nodrošina gāzu apmainu (ir "elpojoši”), to sastāvā esošā kūdra un sapropelis spēj absorbēt nepatīkamas smakas un ēkā veidot antibakteriālu vidi. Pētījumā iegūtie rezultāti pierāda, ka sapropel̦akokskaidu plātnes ir perspektīvas izmantošanai Latvijas apstāklı,os, jo ir ar augstu salizturību un noturību pret izmain̄ām sasalšanas-atkušanas ciklos.

\section{LITERATŪRAS SARAKSTS}

[1] Segliņš, V., Brangulis, A. Latvijas zemes dzị̣ı resursi. Rīga: Tehniskās Universitātes tipogrāfija, 1996.

[2] Brakšs, N., Alksne, A., Ābolinšs, J., Kalniņš, A. Sapropeḷa un kūdras humīnskābes kā saistviela koksnes atlikumu izmantošanā. Zinātņu akadēmijas Vēstis, 1960, 10(159), lpp. 101. - 108.

[3] Vimba, B. Sapropeḷa termiskā šḳīdināšana un iegūto produktu k̦īmiskais raksturojums. Rīga: Latvijas Lauksaimniecības Akadēmija, 1956.

[4] Stankeviča, K. Sapropeḷa īpašības un tā izmantošanas iespējas: Maǵistra darbs. Rīga: Latvijas Universitāte, 2011

[5] Vucāns, A. Pagaidu ieteikumi sapropeḷa pielietošanai augšnnu pamatielabošanai un mēslošanai. Rīga: Latvijas zemkopības zinātniskās pētniecības institūts, 1989, lpp. 2 - 13 .

[6] Štins, S. Ezera sapropẹ̦i un to kompleksa apguve. Maskava: Maskavas Valsts kalnu universitātes izdevniecība, 2005. (krievu val.)

[7] Kurzo, B. V. Sapropę̧a veidošanās un izmantošanas problēmu likumsakarības. Minska, 2005. (krievu val.)

[8] Brakšs, N., Miḷins, N. Pẹtījumi par sapropeḷa kompleksas izmantošanas iespējām ar hidrolīzes un saustvaices metodi. LLA raksti, 1960, IX, p. $471-479$.

[9] Gružāns, A. Sapropeḷbetons. LLA raksti, 1960, IX, lpp. 547 - 561.

[10] Kreijger, C. Ecological properties of building materials. Materials and Structures, 1987, 20, p. 248-254. http://dx.doi.org/10.1007/BF02485919

[11] Indriksone, D. [Rekomendācijas] Using ecological construction materials in the Baltic States. Baltic Environmental Forum, 2011.
[12] Lambie, J. Environmentally Sustainable Building Materials Selection, 2012.

[13] Kruše, M., Kruše, P., Althauss, D., Gabriēls, I. Ekologiiskā būvniecība. Rīga: VAK apvienība Arkādija, 1995. 398 lpp.

[14] Bribián, Z., Capilla, V. Life cycle assessment of building materials: Comparative analysis of energy and environmental impacts and evaluation of the eco-efficiency improvement potential. Building and Environment, 2011, 46, p. 1133-1140. http://dx.doi.org/10.1016/j.buildenv.2010.12.002

[15] Gorenko, P. Būvniecība. Ozolnieki: Latvijas lauksaimniecības konsultāciju un izglītības atbalsta centrs, 2002.

[16] Kymalainen, R., Sjoberg, M. Flax and hemp fibres as raw materials for thermal insulations. Building and Environment , 2008, 43, p. 1261-1269. http://dx.doi.org/10.1016/j.buildenv.2007.03.006

[17] Upeniece, L., Bajāre, D., Korjakins, A. Heat Insulation Materials Made of Foliage Tree Fibres. In: Riga Technical University 53rd International Scientific Conference: Dedicated to the 150th Anniversary and the 1st Congress of World Engineers and Riga Polytechnical Institute. Riga, Latvia, 2012.

[18] Korjakins, A., Toropovs, N., Kara, P., Upeniece, L. Application of Peat, Wood Processing and Agricultural Industry By-products in Producing the Insulating Building Materials. Journal of Sustainable Architecture and Civil Engineering, 2013, 1(2), p. 1 - 7. http://dx.doi.org/10.5755/j01.sace.1.2.2884

[19] Gružāns, A. Sapropeḷbetons. Zinātņu Akadēmijas vēstis, 1958, 12 (137), lpp. $163-170$.

[20] Natureplus e.V. [tiešsaiste]. Insulation materials from renewable raw materials - 2009. [skatīts 05.04.2013.]. Piejams: http://www.natureplus.org/en/natureplus/issuanceguidelines/?user_natureplus_pi3[cat] $=01 \&$ cHash $=\mathrm{d} 77 \mathrm{~d} 398798$

[21] Toropovs, N. Kūdras izmantošana siltumizolācijas materiālu ražošanā. Aktivētās kūdras saistvielas iegūšana un tās izmantošana kūdras/kokskaidu siltumizolācijas kompozītos. Maǵistra darbs. Rīga: RTU Būvniecỉbas fakultāte, Materiālu un konstrukciju institūts. 2012.

[22] Stankeviča, K., Klaviṇš, M., Rūtiṇa, L., Ceriṇa, A. Lake Sapropel: a Valuable Resource and Indicator of Lake Development. Advances in Environment, Computational Chemistry and Bioscience. 2012, p. 247252.

[23] Welltech [tiešsaiste] Environmental Chamber JTH Series - 2013. Sk. 21.04.2013. Piejams: $\quad$ http://www.temperature-humidity chamber.com/download/JTH.pdf.

[24] Lasercomp, [tiešsaiste] Statistics Sheet for FOX600 -- 2012. Sk. 21.04.2013. Pieejams http://www.lasercomp.com/product/fox6xx.php

[25] Instron The diference is measurable [tiešsaiste] 5900 Series - Advanced Mechanical Testing Systems. Instron, - 2013. Sk. 21. 04. 2013. Pieejams http://www.instron.co.uk/wa/product/5900-Series-Mechanical-TestingSystems.aspx

[26] SIA "R\&D Akustika", [tiešsaiste] Materiālu akustisko īpašību testēšana $\begin{array}{llll}\text { impedances caurulē. Sk. 21.04.2013. Piejams: } & \end{array}$ http://www.akustika.lv/rdakust/pdf/16abstrub.pdf

[27] Paroc Group, [tiešsaiste] Skaņas izolācija. Sk. 01.05.2013. Pieejams http://www.paroc.lv/kompetence/skana/skanas-izolacija

[28] Noteikumi par Latvijas būvnormatīvu LBN 016-03 "Būvakustika". Piennemts 01.07.2004. Latvijas Republikas Ministru kabinets. Skatīts: 01.05.2013. Pieejams: http://www.likumi.lv

[29] Kozłowski, B., Mieleniak, B., Muzyczek, M., Mańkowski, J. Development of Insulation Composite Based on FR Bast Fibers and Wool. In: International Conference on Flax and Other Bast Plants. Poznań, Poland, $353-363,2008$.

[30] Biršs, J., Korjakins, A. Būvniecībā izmantojamo materiālu perspektīvas un prasības. RTU zinātniskie raksti, sēr., Materiālzinātne un lietišķā kīmija, 2009, 1(19), lp. 29.-39.

[31] Ulpe, J., Kupče, L. Koka un plastmasu konstrukcijas. Rīga: Zvaigzne. 1991, 23 lpp.

[32] Kasperiūnaitè, D., Navickas, J. Sapropel derivatives in new light. Lithuanian University of Agriculture. 2006, p. 2 - 32.

[33] Šinka, M., Korjakins, A., Šahmenko, G. Kaņepju spaḷu ar hidauliskā kaļ̣a saistvielu izmantošana siltumizolācijas materiālos. In: Biznesa augstskolas Turība konferenču rakstu krājums XIII starptautiskā zinātniskā konference ilgtspējīga uzñèmējdarbība mainīgos ekonomiskos apstāklıs. Rīga, Latvija, 305. - 312.,lpp., 2012

[34] SIA Eko Siltums PLUS, [tiešsaiste]. Dažādu siltumizolācijas materiālu rādītāju salīzzināšanas tabula. Sk. 01.04.2013. Pieejams: http://www.siltumsplus.lv/lv/?option=technical_description\&submenu=c ompare_tables 
[36] Vides Aizsardzības un reǵionālāsa attīstības ministrija [tiešsaiste]. Dabīgā jeb organiskā siltumizolācija. Sk. $\quad 01.04 .2013$ Pieejams http://www.videsrisinajumi.lv/index.php?option=com_content\&view=art icle\&id $=115 \&$ Itemid $=208 \&$ lang $=1 \mathrm{v}$

[37] LVS EN 13168:2002+AC [Standarts] [tiešsaiste]. Fibrolīta plātnes būvniecībai. $\quad$ Skatits: $01.05 .2013 . \quad$ Pieejams: https://www.lvs.lv/lv/services/catalogue/standardDetails.asp?std=20125

[38] Sutton, A. Black, D. Natural fibre insulation: An introduction to lowimpact building materials. University of Bath. 2011.

[39] Berge, B. The ecology of building materials. USA: Architectural Press (an imprint of Elsevier). 2009, 447 lpp.

[40] Isaksson, C., Karlsson, F. Indoor climate in low-energy houses-an interdisciplinary investigation. Building and Environment, 2005, 41, p. 1678-1690. http://dx.doi.org/10.1016/j.buildenv.2005.06.022

[41] Ministru kabineta noteikumi. Piennemts 01.01.1996 Noteikumi par Būvnormatīvu LBN 201-96 "Ugunsdrošǐbas normas". [skatîts 18.04.2013.]. Pieejams: http://www.liis.lv/mspamati.

[42] Meža attīstīibas fonds. Koksnes materiālu uguns reakcijas un mehānisko īpašǐbu pētījumi un jaunu produktu izstrāde. Jelgava, LR ZM Lauku atbalsta dienests, 2008.

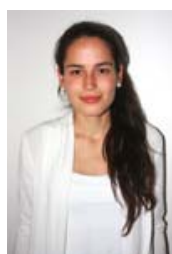

Vaira Obuka: B.sc.env. (2013), Mg.sc.env. student in Environmental Science at the University of Latvia, Faculty of Geography and Earth Science. 2013 year of studying I was environmental laborant at the laboratory of environmental monitoring (Department of Environmental Sciences, Faculty of Geography and Earth Sciences, University of Latvia). The major interests are related to sustainable development, use of sapropel, ecological building materials, thermal insulation materials.

Address: University of Latvia, Raina bulv. 19, LV-1586, Riga, Latvia. E-mail: vaira.obuka@lu.lv

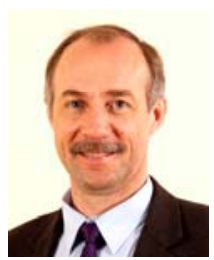

Aleksandrs Korjakins, Graduated Riga Technical University (former Polytechnical Institute) in 1985, as engineer of Civil Engineering. PhD degree in 1997. PhD thesis: Interlaminar Fracture Toughness of Glass Fibre Reinforced Polymeric

Composites Influenced by Fibre Surface Treatment,

Products Author ofmore than 100 publications and 4 patents.Fields of study: building materials, constructions, recycling of building materials, ecological building materials, nanoconcrete, porous

ceramics, numerical methods and computer analysis of structures, Head of Chair of Building Materials and Products. Kalku str. 1, LV-1658, Riga, Latvia. E-mail: aleks@latnet.lv

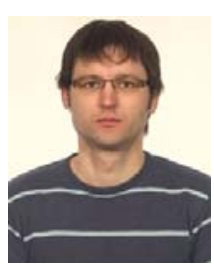

Raitis Brencis, Dr.sc.ing. (2013) Latvia University of Agriculture, Faculty of Rural Engineering, department of Architecture and Building, Jelgava, Latvia

Lecturer at Latvia University of Agriculture; Engineer at SIA „Aspectus”, Building Project leader at SIA „Zemgales tehnologiskais centrs”. Member of Latvia Civil engineers union.

Adress: Akademijas street 19, Jelgava, Latvia Phone: +37163028791

E-mail: raitis.brencis@llu.lv

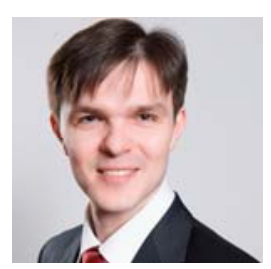

Ilmārs Preikšs, Mg.sc.ing. (2011), Latvia University of Agriculture, Faculty of Rural Engineering, Jelgava, Latvia.

Doctoral student, Lecturer and Researcher at Latvia University of Agriculture, Faculty of Rural Engineering, Department of Architecture and Construction.

Field of research: innovative building materials Address: 19 Akademijas iela, Jelgava, LV-3001, Latvia. E-mail: ilmars.preikss@gmail.com

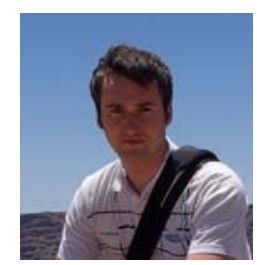

Oskars Purmalis ( $\mathrm{PhD}$ student) received his bachelor's degree in environmental sciences from University of Latvia (Faculty of Geography and

Earth sciences) in 2006 and master degree in 2008

Since the 2008 he is PhD Student and reseacher at the laboratory of environmental monitoring (Department of Environmental Sciences, Faculty of Geography and Earth Sciences, University of Latvia). The major interests are related to environmental chemistry, environmental proceses and nature conservation. $\mathrm{He}$ is a member of the International Humic Substances Society since 2006. Address: Raina bulv. 19, LV-1050, Riga,Latvia

E-mail: oskars.purmalis@lu.lv

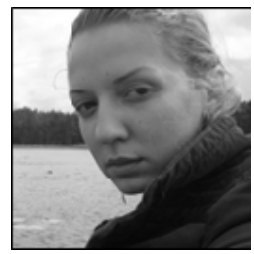

Karina Stankeviča: Mg.sc.env., Ph.D. student in Environmental Science at the University of Latvia, Faculty of Geography and Earth Science. Professional Bachelor of Landscape Architecture and Planning, Latvian University of Agriculture in 2009. Master degree in Environmental Science earned at the University of Latvia in 2011. The major field of study: water objects in landscape, limnic freshwater ecosystem, lake's organic rich sediments properties and possibilities of use, humic substances. Address: University of Latvia, Raiņa bulv. 19, LV-1586, Riga, Latvia. E-mail: karina.stankevica@lu.lv

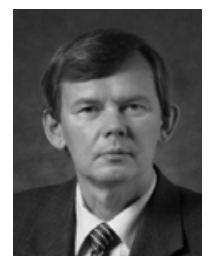

Maris Klavins, Dr. hab. chem., Professor at the University of Latvia, Faculty of Geography and Earth Sciences, Department of Environmental Sciences. M. Klavins obtained his scientific degree in chemistry of biologically active compounds at the Moscow State University in 1986 but a habilitation degree at the University of Latvia in 1994. He is a member of the Academy of Sciences of Latvia, coordinator of International Humic Substances Research Society (IHSS). Research interests are related to studies of natural organic matter, wetlands and bogs and environmental pollution problems.

Address: University of Latvia, Raina bulv. 19, LV-1586, Riga, Latvia.

E-mail: maris.klavins@lu.lv

Vaira Obuka, Aleksandrs Korjakins, Raitis Brencis, Ilmārs Preikšs, Oskars Purmalis, Karina Stankeviča, Māris Kḷavin̄̌s. Sapropel/Peat-Wood Chip Insulation Materials and Their Properties

We live in the world, where the population rapidly increases, and local municipalities and governments should think about possibilities of providing sustainable development. The building of new constructions demands many resources. At this time when people pay more attention to ecological building and saving energy resources, the research on local resources and their potential use is very topical, especially, when thinking not only of new buildings, but also of the renovation of existing constructions and heat insulation. Therefore, the sustainable use of local resources as thermal insulation materials is innovative.

In Latvia, there are quiet many peat and sapropel resources, which can be successfully used to create new innovative products. The aims of the research are to make heat insulation materials and to establish their optimal composition and properties. In this study, we made thermal insulation materials using activated peat, sapropel and wood chips and described their properties in comparison with the industrially produced materials.

We tested the optimal composition of products as well as their mechanical, heat insulation and acoustic properties. Results have shown that the obtained materials can be successfully used in constructions as heat insulation materials and elements of constructions. Materials have good thermal insulation capability and stability in our climatic conditions. Parameters of materials and their potential applications can be used to evaluate the development of ecological building and the use of local resources. 
Вайра Обука, Александр Корякин, Райтис Бренцис, Илмарс Прейкш, Оскар Пурмалис, Карина Станкевича, Марис Клявиньш. Сапропель- и торфодревесностружечные теплоизоляционные плиты и их свойства

При современных темпах роста городского народонаселения строительная индустрия требует все больше минеральных ресурсов и энергии для создания жилья и инфрастуктуры. Одновременно приходится уделять внимание экологическому аспекту экономии ресурсов и энергии. В этом контексте, весьма актуальны возможности использования местных минеральных и биологических ресурсов при создании новых строительных материалов или улучшения свойств существующих (тепло- и звукоизоляции и др.).

Для Латвии, обладающей значительными ресурсами залежей торфа, сапропеля и высоким уровнем использования древесины в строительстве, весьма актуально создание на их основе новых инновационных материалов.

Полученные показатели механических, звукоизоляционных и теплоизоляционных свойств торфодревесностружечных и сапропельдревесностружечных композитных плит довольно высокие и сравнимы с представленными на рынке подобными материалами. Иследованные сапропель- и торфодревесностружечные композитные плиты возможно применить в экологическом градостроительстве как теплоизоляционный материал, а также с целью повышения механической устойчивости конструкций зданий. Полученные материалы хорошо обеспечивают газообмен в помещениях (стены «дышат»), сапропель и торф, входящие в состав этих плит абсорбируют неприятные запахи и образуют в помещениях антибактериальную среду.

Результаты исследований показывают, что использование сапропель- и торфодревесностружечных композитных плит в строительстве в условиях Латвии весьма перспективны, поскольку обладают повышенной морозоустойчивостью и устойчивы в периоды всего цикла промерзания и оттаивания. 